\title{
A Comprehensive Review on the Prevalence and Dissemination of Some Bacterial Diseases in Ornamental Fishes and Their Preventive Measures
} Arnab Chatterjee ${ }^{1 \#}$, Sucharita Ghosh ${ }^{2 \#}$, Ritwick Bhattacharya ${ }^{1 \#}$, Soumendranath Chatterjee ${ }^{2}$, Nimai Chandra Saha ${ }^{1 *}$

${ }^{1}$ Fishery and Ecotoxicology Research Laboratory (Vice-Chancellor's Research Group), Department of Zoology, the University of Burdwan, Burdwan 713104, West Bengal, India

${ }^{2}$ Parasitology \& Microbiology Research Laboratory, Department of Zoology, the University of Burdwan, Burdwan, West Bengal, India \#Authors contributed equally

*Corresponding author: Nimai Chandra Saha

Abstract

As a consequential sector within the fisheries segment, ornamental fisheries have become a billion-dollar industry. At current, it is estimated that the aquarium industry is worth about 15 billion dollars. In ornamental aquaculture and aquarium keeping, the incidence of diseases is the main quandary that emerges during culture and deplorably affects the profitability of the ventures. Diseases are caused by viruses, protozoa, bacteria, fungi, and parasites under profound culture conditions, and the likelihood of stress elevates in an immensely colossal portion of the stock. Of these, the most paramount causes of sudden fish death are infectious and bacterial diseases. Nowadays, veterinary antibiotic treatment of contaminated fish is being applied in most of the States of India. Disease obviation is often less costly than treating disease outbreaks when it is subsisting. Adopting and implementing a health management strategy would not assure a disease-free facility that ultimately leads to considerably decremented chances of dissemination of diseases. In the present report, an effort has been made to review in detail the main bacterial diseases occurring in the ornamental fish along with their obviation.

Keywords: Ornamental fish; ornamental fish trade; bacterial disease; disease control; health management.

Copyright ( 12020 The Author(s): This is an open-access article distributed under the terms of the Creative Commons Attribution 4.0 International License (CC BY-NC 4.0) which permits unrestricted use, distribution, and reproduction in any medium for non-commercial use provided the original author and source are credited.

\section{INTRODUCTION}

Aquarium maintenance is the second most immensely colossal hobby on the planet, and because of its immense financial opportunities, the ornamental fish industry is gaining prominence [1]. Ornamental fish conservation was developed in the 18th century as just a hobby with goldfish [2]. Aquarium maintenance and ornamental fish farming became macro cosmically acknowledged in the 20th century. Virtually $90.0 \%$ of Freshwater ornamental fish are bred in captivity waters [3]. It has been estimated that approximately 25 of 8,000 ornamental aquatic organisms are not facilely grown [4]. Many high-value aquatic ornamental fish are consequently extensively bred and domesticated. In more than 125 countries of the World with a market value of over $\$ 10$ billion, marine and freshwater ornamental fish are traded. Over 2500 fish species, more than 60 percent of which emanate from freshwater are involved. The universal market is expected to be dominated by about 30 freshwater fish species [5]. The marine species represent over $15 \%$ of the market, with about $98 \%$ obtained from the wild while the remaining species are captive bred [6]. Since 2000, universal exports of ornamental fish have grown steadily from
177.7 million USD in 2014 to 347.5 million USD [5]. It is estimated that the world trade in ornamental fish is over US\$ 15 billion and that more than 2 billion live ornamental fish is exported [1]. 99\% of the global market is confined to hobbyists and less than $1 \%$ is used for public aquaria and research institutes. In the world, developed countries offer more than 60 percent of ornamental fish to global producers and suppliers [7]. The 2016 global export value for ornamental fish was US\$ 337.70 [8]. A close glance at the top ten export-market areas, which supplied $78.6 \%$ in 2014 , found that Asian countries made up more than $57 \%$ of trade for exports at US\$ 197.7 million. In 2014, by country, Singapore, with its US\$ 69.32 million worth of exports, was the world's ornamental fish capital [8]

India has a wide assortment of fish, huge numbers of which are very appropriate for ornamental purposes. The contribution of India to foreign trade in ornamental fishes is, however, minimal standing at 1.6 million US\$ (2016) [9]. The export of ornamental fish from our country began with some tropical freshwater species in 1969. Over the years there has been a growing trend and exponential rise in exports of ornamental fish from India. India's global market share in 1991-2009 
ranged from 0.12 to 1.16 percent. The export value in 2016 was US\$ 1.06 million for the Indian ornamental fish industry, which accounted for 0.3 percent of the overall export value [10]. In the World Exporting Countries ranking, India ranks 31 st. India is a nation with high biodiversity with approximately 374 ornamental freshwater species and approximately 700 indigenous ornamental fish [5]. Around $90 \%$ of the ornamental fish are traded from the port of Kolkata, then $8 \%$ from Mumbai and 2\% from Chennai [8]. A good atmosphere, modest labor, and simple distribution make India plausible for ornamental aquaculture [11]. The National Fisheries Council has familiarised itself with various sponsoring projects aimed at promoting minute-scale integrated ornamental fish farming, thereby providing urban and rural youth job opportunities [12]. However, the outbreak of disease is the bottleneck during raising and building up the broodstock and during reproducing and raising of ornamental fishes [13]. There are frequently high mortality rates in ornamental fishes due to the potential risks, especially infection incursions, and parasite assaults [14]. Several economically consequential diseases are registered and typical bacterial diseases, signs, prevalance and spreading of the diseases along with their obviation in the ornamental fishes are summarised in this article, along with their treatment protocols.

\section{What are ornamental fishes?}

The ornamental fishes are one of the most important commercial sectors of fisheries that provide millions of dollars of profits and support the livelihood of peoples of some developing countries. These fishes are popular around the globe due to their minimum requirements, space and easy maintenance in aquaria. Ornamental fishes are those kept in artificial habitat for aesthetic purposes. They are reared for their vibrant coloration and attractiveness [15].

Some commonly reared ornamental fishes along with their origin and characteristics are listed in Table-1.

Table-1: Origin and characteristics of some common ornamental fishes

\begin{tabular}{|c|c|c|c|}
\hline $\begin{array}{l}\text { Common } \\
\text { name }\end{array}$ & Scientific name & Origin & Characteristics \\
\hline Angelfish & Pterophillum scalare & South America & Variation in color and pattern, omnivorous \\
\hline Molly & $\begin{array}{l}\text { Mollienisia lapipinna, M. } \\
\text { sphenops, M. vetifeara }\end{array}$ & Mexico, Gulf Coast, Yucatan & Small, omnivorous \\
\hline Goldfish & Carassius auratus & East Asia & Red/orange in color with large eyes \\
\hline Gouramies & $\begin{array}{l}\text { Trichogaster lalius (dwarf } \\
\text { gourami), T. leerii (pearl), } \\
\text { Osphronemus sp. (giant gourami), }\end{array}$ & Southeast Asia & $\begin{array}{l}\text { Moderate to large-sized, different color } \\
\text { and pattern according to variety }\end{array}$ \\
\hline Guppy & Poecilia reticulata & South America & $\begin{array}{l}\text { Males are more colorful and vibrant than } \\
\text { females }\end{array}$ \\
\hline Koi carp & Cyprinus rubrofuscus & Japan, China & $\begin{array}{l}\text { Huge variation in color, scalation and } \\
\text { pattern. Omnivorous. Live up to } 100-200 \\
\text { years }\end{array}$ \\
\hline $\begin{array}{l}\text { Betta/ } \\
\text { Fighter fish }\end{array}$ & Betta splendens & Southeast Asia & $\begin{array}{l}\text { Vibrant coloration. Males are extremely } \\
\text { aggressive }\end{array}$ \\
\hline Platy & Xyphophorus maculatus & North and Central America & Huge range of color variety \\
\hline Zebrafish & Danio rerio & $\begin{array}{l}\text { India, Nepal, Bangladesh, } \\
\text { Myanmar, Pakistan }\end{array}$ & $\begin{array}{l}\text { Horizontal blue stripes on side of the body, } \\
1.8-4 \mathrm{~cm} \text { in length }\end{array}$ \\
\hline Ticto Barb & Puntius ticto & $\begin{array}{l}\text { India, Nepal, Bangladesh, Sri } \\
\text { Lanka, Myanmar, Pakistan }\end{array}$ & Silver to gold in color with two black spots \\
\hline Swordtail & Xyphophorus helleri & $\begin{array}{l}\text { Mexico, Northern Central } \\
\text { America }\end{array}$ & $\begin{array}{l}\text { Different color variations. Small-sized } \\
\text { with a sword-shaped extension of the } \\
\text { caudal fin }\end{array}$ \\
\hline Neon tetra & Paracheirodon innesi & South America & Bright coloration with blue stripes \\
\hline
\end{tabular}

\section{The occurrence of disease in ornamental fishes}

However, these delicate fishes are very much prone to different types of diseases due to their sensitivity towards the surrounding environment [16]. The common causes of fish disease fall under six broad categories like environment-related disease (such as temperature, poor water quality, etc), nutritional disease, genetic disease, physical injuries, disease through biological organisms and/or combination of these factors. Diseases like tail and fin rot, columnaris disease, white spot disease, popeye disease, dropsy, slimy skin disease are common in ornamental fishes. Infection due to nematodes, lice and flukes are also common in ornamental fishes [17].

\section{Common symptoms of fish disease}

Loss of appetite and color, sluggishness, irregular swimming behavior, etc. are some most common symptoms of diseased fish. Overall, skin lesions, systemic infections, corneal opacity, and 
septicemia are among the clinical symptoms of the fish disease [18]. These diseases are commonly caused by both primary and secondary pathogen infections [19]. Gram-negative bacteria including Pseudomonas, Aeromonas, Vibrio, etc are the most common causative agents of ulceration and lesions of the skin [20].

\section{Bacterial disease of ornamental fishes}

Among different type of pathogens, bacteria causes significant mortality and morbidity in ornamental fishes [21]. During the period 2014-18, under a passive surveillance program at Freshwater Aquaculture Farms of Eastern India, a total of 219 cases of fish mortalities was reported [22]. Parasitic diseases contributed $74.88 \%$ of fish mortality among different disease incidences followed by bacterial diseases of $12.79 \%$ and both bacterial and parasitic pathogenic agents together account for $10.50 \%$ of disease incidence [23]. Aquarium fishes are more susceptible to disease due to their habitat space limitations [24]. Many stress factors including poor water conditions, overcrowding, inadequate nutrition, etc. are the major causes of bacterial infection in ornamental fishes [13]. Among bacterial disease, the aeromonads group itself accounts for a major portion, i.e., $66.66 \%$ of diseases [25].

\section{Most common disease-causing bacteria in ornamental fishes}

Among different bacterial pathogens, Gram-negative bacterias are the most prevalent disease-causing agents in ornamental fishes. Several disease-causing bacterial genera like Aeromonas, Citrobacter [26], Vibrio [27], Francisella [28], Edwardsiella [29], Flavobacterium [30], Shewanella [31] and Plesiomonas [32] were reported by previous researchers.

Moreover, 27 different bacterial species that cause different diseases in ornamental fishes has been reported [26]. Among different bacterial species, Aeromonas veronii [30.8\%] and A. hydrophila [18.7\%] are the most abundant ones followed by Citrobacter freundii [7.1\%], Shewanella putrefaciens [7.1\%], Pseudomonas spp. [6.6\%], Shewanella baltica [4.9\%], and Plesiomonas shigelloides [3.3\%].

Aeromonas sp. is possibly the most frequently encountered bacterial pathogen of freshwater ornamental fish [26]. A. hydrophila is a Gram-negative, oxidase-positive, aerobic and facultative anaerobic, motile bacterium that was found more infectious and caused septicemia in ornamental fish [33].

Escherichia species are widely distributed Gram-negative, non-spore-forming, rod-shaped bacteria of the Enterobacteriaceae family that causes several diseases in ornamental fishes [34].
Edwardsiella species are Gram-negative, rod-shaped bacteria that cause Edwardsiellosis in ornamental fishes. Edwardsiella tarda is reported as a causative agent of the disease in many commercially important marine and freshwater fishes [35].

Yersinia ruckeri is the causative agent of enteric red mouth [ERM] disease. It is a widespread, Gram-negative, straight rod-shaped, non-spore-forming bacteria living in fresh-water environments [36].

Among different Mycobacterium spp., M. marinum, M. fortuitum and $\mathrm{M}$. chelone are the most prevalent pathogens in ornamental fish [37].

Enterobacter cloacae and Pseudomonas putida are opportunistic pathogens of the Enterobacteriaceae family that infect both humans [38] and other organisms such as insects [39] and fish [40]. P. aeruginosa and P. fluorescens are among the most common opportunistic pathogens of freshwater fish [41]. Besides these two species, other diseases causing bacteria of Pseudomonas are P. mosselii, P. alcaligines, P. monteilii, P. marginalis, P. oleovorans, P. koreensis, and P. nitroreducens [26].

Another bacterial pathogen Shewanella. putrefaciens were reported to causes skin ulcers, exophthalmia, dark patches on the skin, and ascites were. Shewanella sp. were isolated from 11 freshwater fish species including Guppy, Zebrafish, Platy, Goldfish. Shewanella species seem to be common pathogens of ornamental and pond-raised fish in Poland [26].

\section{Common bacterial diseases prevalent in ornamental fishes Mouth fungus/ Columnaris}

Mouth fungus is known because it seems to be a fungal mouth attack. It is attributed to the Flexibacter columnaris bacterium. It occurs first as a grey or white line across the lips, and then as small tufts that sprout like a fungus out of the mouth. Loss of appetite and trouble breathing are major indicators of behavior. The common symptoms are white patches around the mouth resembling the cotton-like structure. Unless treated at an early stage, the toxins produced and the failure to feed would be lethal. It's infectious. Sometimes a second infection of an Aeromonas bacteria is often associated with this bacteria. Infection with Flexibacter columnaris is often correlated with situations of stress. Risk factors are hot water $\left(25^{\circ}-32^{\circ} \mathrm{C}\right)$, crowding, lesions and poor water content (low oxygen and elevated free ammonia) for Columnaris disease.

\section{Dropsy}

Bacterial infection in the kidney of fish causes dropsy that may lead to renal dysfunction and fluid accumulation. Common symptoms include protruding scales, bloating of the body and swollen belly. Fluid retention of the body leads towards the swollen belly and 
blotted body with protruded skin. In severe stages of infection, the bloating of internal organs also occurred.

\section{Red pest}

Red pest disease is also termed as hemorrhagic septicemia that causes ulcerations in the tail and fins which may lead towards rotting and falling off of tail and fin in severe conditions. A higher level of damage occurs when the bacteria enter the circulatory system and travels into different organs such as the heart through the blood vessel. Common Symptoms of this disease include bloody streaks on fins, tail and body surface, blotted abdomen, bulging eye, irregular swimming and hyperventilation.

\section{Tail Rot and Fin Rot}

In most cases Pseudomonas spp. is found as the causative agent of this disease [42]. Pseudomonas is a Gram-negative rod-shaped non-spore-forming bacteria. This infection during its early phase emerged as a white streak on the fringes of the fins. Poor water conditions, fungal infection and other stress factors may trigger this disease. It begins from the boundaries of fins and continues by destroying more and more tissue. On reaching the fin base it starts to attack the body and eventually leads to body rot. Bloody fin rays, skin ulceration, disintegrated reduced fins, cloudy eyes, redness on fin base and edges are some signs of this disease.

\section{Tuberculosis}

Tuberculosis is caused by several species of Mycobacterium like Mycobacterium chelonae, $\mathrm{M}$. flavescens, M. fortuitum, M. marinum. M. piscium, M. fortuitum, etc [42]. Mycobacterium flourishes in acidic $\mathrm{pH}$. Fish infected by Mycobacterium become pale and lethargic. Skin ulceration, fin and scale loss, swollen belly, frayed fins, and loss of appetite are common features of infected fish. Nodules on eyes and body surfaces may be observed on the progression of the disease. Hiding tendency, refusing to eat are some behavioral signs of tuberculosis.

\section{Fish Vibriosis}

Vibriosis is caused by a variety of Vibrio bacteria which are Gram-negative comma-shaped, facultative anaerobes. Bleeding occurs when bloodstreams or reddening develop under the skin surface and becomes red spots on the ventral and lateral areas of the fish. The common symptoms are drowsiness, accelerated breathing, reduced appetite, skin bleeding, and mortality. Moreoevr, dark swollen lesions evolve to become ulcers, spreading bloody pus. Eye complications with the cloudy eye will also result in pop-eye and loss of the eye. The vibriosis infection typically takes place very quickly in fish. The majority of infected fish die without any visual signs than ulcers, and death can often occur unexpectedly before signs are detected.
Scale protrusion

Scale protrusion is common in aquarium fish. Lack of nutrient supply might be a reason otherwise bacterial infection could lead to this diseased condition. At the primary stage, scale protrusion is observed without any swelling of the body. With the progression of the disease, scales become loose and eventually shed from the body.

\section{Furunculosis}

This is an extremely contagious disease that affects aquarium fish of all ages. Furunculosis causes lesions on muscle, spleen enlargement, sepsis and hemorrhage. It is very common to Goldfish and Koi. it is caused by Aeromonas Salmonicida which is again a Gram-negative rod-shaped facultative anaerobic bacteria [42]. This bacterium contains a unique surface protein called A-layer which is supposed to be responsible for its virulent traits [43].

\section{Bacterial Kidney Disease (BKD)}

This bacterial disease is caused by a gram-positive namely Renibacterium salmoninarum. Clinical signs often are not visible externally, sometimes hemorrhagic lesions and paleness on the skin and later stage swelling of the kidney are noticed.

This disorder can be transferred by the eggs and even by the oral pathway and skin degradation. Contaminated food and water can provide the source of the infection.

\section{Popeye/Exophthalmia}

Exophthalmia is caused by infection of Aeromonas Punctata that leads towards hemorrhage in the capillaries of the eye socket and affects both single or both eyes.

\section{Swim Bladder Disease}

It infers to issues that detrimentally affect the swim bladder of fish It may be attributed to infection of bacteria or parasites. Common signs include bloated belly, curved spine etc. Fish sinks and becomes challenging to rise. Fish float upside-down to the surface.

\section{General Septicemia}

Aeromonas hydrophila is responsible for this type of disease. Bacteria of this sort are present in the blood of fish. This disease exhibit skin ulcers, aggravated abdomen and swollen fin and fin bases.

Treatments of the bacterial diseases prevalent in ornamental fishes along with their preventive measures

Ornamental fishes are delicate, sensitive, and vulnerably susceptible to numerous diseases. The diseases can occur due to poor water quality, temperature vacillation, poor quality feed, etc. General 
symptoms in diseased fishes incline to be the loss of appetite and color, sluggishness, aberrant swimming activity, etc. Specific diseases such as the red tail, columnaris, and white spot conditions are observed. Sundry aquatic fishes are additionally afflicted with velvet skin disease, popeye disease, dropsy, etc. In several cases, fluke attacks, fish lice, and anchor worm may lead to ectoparasite infection. Several ornamental fish disease problems start due to various external infections. If not tested, pathogens can become systemic, which can lead to the death of the fish affected. The felicitous utilization of $\mathrm{KMnO}_{4}$ will efficaciously control a wide number of bacteria, parasites, and fungal agents afore systemic infections are created. The fish owner preserves money because the utilization of dispensable antibiotics is minimized and the occurrence of bacterial resistance is abbreviated. In ornamental trade, the right utilization of $\mathrm{KMnO}_{4}$ when an infection commences will expedite the kineticism of fish as they do not have to be held on antibiotic therapy for a long period (often for 10 to 14 days). The diseased ornamental fish must be isolated from each other and given moderate 'dip-treatment' with $\mathrm{KMnO}_{4}(0.002 \%)$. To eschew certain bacterial infections, chloromycetin is added at the rate of $40 \mathrm{mg}$ in $5 \mathrm{~L}$ of water in the aquarium tank. In the event of high astringency of a disease, the aquarium should be washed with disinfectants like $\mathrm{KMnO}_{4}$ or malachite green. The seriously affected fish should be taken out to forestall further sickness transmission.

Treatments of some commonly prevalent bacterial diseases of ornamental fishes using diverse arrays of pharmaceutical drugs are portrayed below.

Mouth fungus/ Columnaris: $\mathrm{NaCl}$ (Common Salt) is an efficient treatment for all parasitic fish diseases at 100 $\mathrm{kg} / \mathrm{ha}$ with lime $200 \mathrm{~kg} / \mathrm{ha}$ at 4-day spraying interval. Additional therapy with OTC-5 g/100 kg of fish or mix Terramycin (OTC) in feed at 5\% avoids a secondary infection caused by bacteria.

Dropsy: $1 \%$ of chloramphenicol and/or tetracycline is used after proper mixing with flake food as a treatment of this disease.

Red pest: $0.2 \%$ solution of monacrin (monoaminoacridine) and/or acriflavine (trypaflavine) is used at the rate of $1 \mathrm{ml} / \mathrm{l}$ in water for treatment. Then with flake food, $1 \%$ of the antibiotics can be used after proper mixing.

Tail Rot and Fin Rot: Dip treatment in $500 \mathrm{mg} / \mathrm{l}$ of copper sulphate solution for 1 minute over 3-4 days is an effective preventive measure against tail and fin rot.

Fish Vibriosis: Kanamycin is one of the best antibiotics for its treatment although chloramphenicol or furazolidone is also fine. While using antibiotics, it has to be contained in a quarantine tank instead of the primary aquarium. This is because antibiotics will destroy the biological filter in the main tank, reversing the nitrification cycle and creating an ammonia and nitrite surge just a few days later [42].

Scale Protrusion: Treatment with antibiotic chloramphenicol or tetracycline is found effective against scale protrusion. Antibiotic is generally provided with flake food at a ratio of 1:100 after proper mixing. Fish should readily consume this mixture if they kept hungry.

Furunculosis: Dip treatment in 1:2000 copper sulphate solution for 1 minute over 3-4 days is an effective preventive measure against furunculosis.

Bacterial Kidney Disease (BKD): Clindamycin, erythromycin, penicillin $\mathrm{G}$, spiramycin and lincomycin can be considered for BKD disease.

\section{CONCLUSION}

Though there is vigorous demand in the international markets for Indian indigenous ornamental fish, minuscule numbers are exported for sundry reasons. Secondly, there is a diminutive interest in breeding indigenous fish, which are not prevalent in the domestic markets. One of the major reasons of this decrement in ornamental fish production is prevalence of bacterial diseases, ergo treating the bacterial diseases is very consequential, as demand for its culture is incrementing in both domestic and foreign markets. A precautionary step, including quarantining fresh fish, needs to be taken afore integrating into the subsisting stock. Maintaining appropriate husbandry and water quality are the keys to disease control. If government agencies are inclined to establish sizably voluminous-scale facilities and provide breeders with special training and support, more ornamental local fish can be produced from the country to raise exports.

\section{ACKNOWLEDGEMENT}

The authors are thankful to the Department of Zoology, The University of Burdwan, West Bengal, India for providing all sorts of scientific resources and appropriate facilities to conduct this review work.

Conflict of Interest: The authors declare that there is no conflict of interest.

\section{REFERENCES}

1. Biondo MV, Burki RP. A Systematic Review of the Ornamental Fish Trade with Emphasis on Coral Reef Fishes_-An Impossible Task. Animals. 2020 Nov 1;10(11):2014.

2. Novák J, Kalous L, Patoka J. Modern ornamental aquaculture in Europe: early history of freshwater fish imports. Rev Aquac. 2020 Feb 19;12421.

3. Sharma M. Ornamental fish rearing and breeding- a 
new dimension to aquaculture entrepreneurship in Himachal Pradesh. 2020;8(2):157-62.

4. Kumar ST, Charan GB, Kumar SS. Review of the research on the fish diversity in the river Mahanadi and identifying the probable potential ornamental fishes among them with reference to threats and conservation measures. Res. J. Animal, Veterinary and Fishery Sci. 2013;1(3):16-24.

5. Raja K, Aanand P, Padmavathy S, Sampathkumar JS. Present and future market trends of Indian ornamental fish sector. Int J Fish Aquat Stud. 2019;7(2):6-15.

6. Nagar K, Box P. Potential of Ornamental Fish Culture and Marketing. 2014;1(3):119-25.

7. The state of world fisheries and aquaculture Part 1. Available from: http://www.fao.org/3/x8002e/x8002e04.htm

8. Dey VK. The Global Trade in Ornamental Fish. Infofish Int. 2016;4:52-5.

9. Jain A, Surnar S, Saini VP, Ojha ML. Biodiversity of indigenous ornamental fish in Wakl river system of Southern Rajasthan. 2019;7(4):293-8.

10. Satam SB, Sawant NH, Ghughuskar MM, Sahastrabuddhe VD, Naik VV, Pagarkar AU. Ornamental Fisheries: A new Avenue to Supplement Farm Income. Adv Agric Res Technol. 2018;2(2):193-7.

11. Stevens CH, Croft DP, Paull GC, Tyler CR. Stress and welfare in ornamental fishes: what can be learned from aquaculture? J Fish Biol. 2017 Aug 1;91(2):409-28.

12. Ukwe OK, Edun O, Akinrotimi O. Aquaculture and fisheries: A recipy for job creation. Int J Res Under Literal Access. 2018;1(4).

13. Marudhupandi T, Kumar TTA, Prakash S, Balamurugan J, Dhayanithi NB. Vibrio parahaemolyticus a causative bacterium for tail rot disease in ornamental fish, Amphiprion sebae. Aquac Reports. 2017 Nov 1;8:39-44.

14. Santos MA, Jerônimo GT, Cardoso L, Tancredo KR, Medeiros PB, Ferrarezi JV. Parasitic fauna and histopathology of farmed freshwater ornamental fish in Brazil. Aquaculture. 2017;470:103-9. Available from: http://dx.doi.org/10.1016/j.aquaculture.2016.12.03 2

15. King TA. Wild caught ornamental fish: a perspective from the UK ornamental aquatic industry on the sustainability of aquatic organisms and livelihoods. J Fish Biol. 2019 Jun 1;94(6):92536. Available from: http://doi.wiley.com/10.1111/jfb.13900

16. Preena PG, Dharmaratnam A, Raj NS, Kumar TVA, Raja SA, Swaminathan TR. Antibiotic susceptibility pattern of bacteria isolated from freshwater ornamental fish, guppy showing bacterial disease. Biologia (Bratisl). 2019 Aug 15;74(8):1055-62. Available from: https://link.springer.com/article/10.2478/s11756-0
19-00261-8

17. Pandey G. Treatment and Control of Ornamental Fish Infection. Univers J Pharm. 2013;02(05):7883.

18. Roberts HE, Palmeiro B, Weber ES. Bacterial and Parasitic Diseases of Pet Fish. Vol. 12, Veterinary Clinics of North America - Exotic Animal Practice. 2009:609-38.

19. Wooley RE, Ritchie BW, Burnley VV. In vitro effect of a buffered chelating agent and neomycin or oxytetracycline on bacteria associated with diseases of fish. Dis Aquat Organ. 2004 Jun 11;59(3):263-7.

20. Sudheesh PS, Al-Ghabshi A, Al-Mazrooei N, Al-Habsi S. Comparative Pathogenomics of Bacteria Causing Infectious Diseases in Fish. Int $\mathbf{J}$ Evol Biol. 2012;2012:1-16.

21. Nejad Moghadam S, Safari R, Nahavandi R. Bacterial diseases of ornamental fish. J Ornam Aquat. 2017;4(1):29-34.

22. Sahoo PK, Swaminathan TR, Abraham TJ, Kumar R, Pattanayak S, Mohapatra A. Detection of goldfish haematopoietic necrosis herpes virus (Cyprinid herpesvirus-2) with multi-drug resistant Aeromonas hydrophila infection in goldfish: First evidence of any viral disease outbreak in ornamental freshwater aquaculture farms in India. Acta Trop. 2016 Sep 1;161:8-17.

23. Kotob MH, Menanteau-Ledouble S, Kumar G, Abdelzaher M, El-Matbouli M. The impact of co-infections on fish: a review. Vol. 47, Veterinary Research. BioMed Central Ltd.; 2016; 1-12.

24. Magnadóttir B. Innate immunity of fish (overview). In: Fish and Shellfish Immunology. Academic Press; 2006; 137-51.

25. PK S, AP, MK S, SP, Kumar PR, BK D. Incidences of Infectious Diseases in Freshwater Aquaculture Farms of Eastern India: A Passive Surveillance based Study from 2014-2018. J Aquac Res Dev. 2020;11(1):1-5.

26. Walczak N, Puk K, Guz L. Bacterial flora associated with diseased freshwater ornamental fish. J Vet Res. 2017 Dec 1;61(4):445-9.

27. Hashem M, El-Barbary M. Vibrio harveyi infection in Arabian Surgeon fish (Acanthurus sohal) of red sea at hurghada, Egypt. Egypt J Aquat Res. 2013;39(3):199-203.

28. Lewisch E, Dressler A, Menanteau-Ledouble S, Saleh M, El-Matbouli M. Francisellosis in ornamental. Bull Eur Assoc Fish Pathol. 2014;34(May):63.

29. Hawke JP, Kent M, Rogge M, Baumgartner W, Wiles J, Shelley J, et al. Edwardsiellosis caused by Edwardsiella ictaluri in laboratory populations of Zebrafish Danio rerio. J Aquat Anim Health. 2013;25(3):171-83.

30. Verma DK, Rathore G, Pradhan PK, Sood N, Punia $P$. Isolation and characterization of Flavobacterium columnare from freshwater ornamental goldfish 
Carassius auratus. J Environ Biol. 2015 Mar 1;36(2):433-9.

31. Pekala A, Kozińska A, Paździor E, Glowacka H. Phenotypical and genotypical characterization of Shewanella putrefaciens strains isolated from diseased freshwater fish. J Fish Dis. 2015 Mar 1;38(3):283-93.

32. Nisha RG, Rajathi V, Manikandan R, Prabhu NM. Isolation of Plesiomonas shigelloides from infected cichlid fishes using 16S rRNA characterization and its control with probiotic Pseudomonas sp. Acta Sci Vet. 2014;42(1).

33. Igbinosa IH, Igumbor EU, Aghdasi F, Tom M, Okoh AI. Emerging Aeromonas species infections and their significance in public health. Vol. 2012, The Scientific World Journal. 2012.

34. Pelli A. Disease Infection by Enterobacteriaceae Family in Fishes: A Review. J Microbiol Exp. 2017;4(5):4-5.

35. Lan J, Zhang XH, Wang Y, Chen J, Han Y. Isolation of an unusual strain of Edwardsiella tarda from turbot and establish a PCR detection technique with the gyrB gene. J Appl Microbiol. 2008 Sep;105(3):644-51.

36. Kumar G, Menanteau-Ledouble S, Saleh M, El-Matbouli M. Yersinia ruckeri, the causative agent of enteric redmouth disease in fish. Vol. 46, Veterinary Research. BioMed Central Ltd.; 2015.

37. Hashish E, Merwad A, Elgaml S, Amer A, Kamal $\mathrm{H}$, Elsadek A. Mycobacterium marinum infection in fish and man: Epidemiology, pathophysiology and management; a review. Vol. 38, Veterinary Quarterly. Taylor and Francis Ltd. 2018:35-46.

38. Conti S, dos Santos SSF, Koga-Ito CY, Jorge AOC. Enterobacteriaceae and Pseudomonadaceae on the dorsum of the human tongue. J Appl Oral Sci. 2009;17(5):375-80.

39. Eugene Sanders WE, Sanders CC. Enterobacter spp.: Pathogens poised to flourish at the turn of the century. Vol. 10, Clinical Microbiology Reviews. American Society for Microbiology; 1997; 220 41.

40. Thillai Sekar V, Santiago TC, Vijayan KK, Alavandi S V., Stalin Raj V, Rajan JJS. Involvement of Enterobacter cloacae in the mortality of the fish, Mugil cephalus. Lett Appl Microbiol. 2008;46(6):667-72.

41. Oh WT, Kim JH, Jun JW, Giri SS, Yun S, Kim HJ. Genetic characterization and pathological analysis of a novel bacterial pathogen, Pseudomonas tructae, in rainbow trout (Oncorhynchus mykiss). Microorganisms. 2019 Oct 1;7(10).

42. Saikia DJ, Chattopadhyay P, Banerjee G, Talukdar B, Sarma D. Identification and Pathogenicity of Pseudomonas aeruginosa DJ1990 on Tail and Fin Rot Disease in Spotted Snakehead. J World Aquac Soc. 2018 Aug 1;49(4):703-14.

43. Beran V, Matlova L, Dvorska L, Svastova P, Pavlik I. Distribution of mycobacteria in clinically healthy ornamental fish and their aquarium environment. J Fish Dis. 2006 Jul;29(7):383-93.

44. Varshney A, Das M, Chaudhary P, Kumari R, Yadav K. Aeromonas Salmonicida as a causative agent for postoperative endophthalmitis. Middle East Afr J Ophthalmol. 2017 Oct 1;24(4):213-5.

45. Dallaire-Dufresne S, Tanaka KH, Trudel MV, Lafaille A, Charette SJ. Virulence, genomic features, and plasticity of Aeromonas salmonicida subsp. salmonicida, the causative agent of fish furunculosis. Vol. 169, Veterinary Microbiology. 2014; 1-7.

46. Lee KK, Liu PC, Chuang WH. Pathogenesis of gastroenteritis caused by Vibrio carchariae in cultured marine fish. In: Marine Biotechnology. 2002; 267-77. 